\title{
High level of oxidized nucleosides in thyroid mitochondrial DNA; damaging effects of Fenton reaction substrates
}

\author{
Małgorzata Karbownik-Lewińska ${ }^{1,3^{*}}$, Jan Stępniak and Andrzej Lewiński ${ }^{2,3}$
}

\begin{abstract}
Background: The mitochondrial DNA (mtDNA) lies in close proximity to the free radical-producing electron transport chain, thus, it is highly prone to oxidative damage. Oxyphilic type of follicular thyroid carcinoma consists of cells filled - almost exclusively - with aberrant mitochondria. In turn, bivalent iron $\left(\mathrm{Fe}^{2+}\right)$ and hydrogen peroxide $\left(\mathrm{H}_{2} \mathrm{O}_{2}\right)$ are indispensable for thyroid hormone synthesis, therefore being available in physiological conditions presumably at high concentrations. They participate in Fenton reaction $\left(\mathrm{Fe}^{2+}+\mathrm{H}_{2} \mathrm{O}_{2} \rightarrow \mathrm{Fe}^{3+}+\mathrm{OH}^{\circ} \mathrm{OH}^{-}\right)$, resulting in the formation of the most harmful free radical - hydroxyl radical ( $(\mathrm{OH})$. The same substrates may be used to experimentally induce oxidative damage to macromolecules. The aim of the study was to evaluate the background level of oxidative damage to mtDNA and the damaging effects of Fenton reaction substrates.
\end{abstract}

Methods: Thyroid mtDNA was incubated in the presence of either $\mathrm{H}_{2} \mathrm{O}_{2}[100,10,1.0,0.5,0.1,0.001,0.00001 \mathrm{mM}]$ or $\mathrm{FeSO}_{4}\left(\mathrm{Fe}^{2+}\right)[300,150,30,15,3.0,1.5 \mu \mathrm{M}]$, or in the presence of those two factors used together, namely, in the presence of $\mathrm{Fe}^{2+}[30 \mu \mathrm{M}]$ plus $\mathrm{H}_{2} \mathrm{O}_{2}[100,10,1.0,0.5,0.1,0.001,0.00001 \mathrm{mM}]$, or in the presence of $\mathrm{H}_{2} \mathrm{O}_{2}[0.5 \mathrm{mM}]$ plus $\mathrm{Fe}^{2+}[300,150,30,15,3.0,1.5 \mu \mathrm{M}]$. 8-oxo-7,8-dihydro-2'-deoxyguanosine (8-oxodG) concentration, as the index of DNA damage, was measured by HPLC.

Results: Both Fenton reaction substrates, used separately, increased 8-oxodG level for the highest $\mathrm{H}_{2} \mathrm{O}_{2}$ concentration of $100 \mathrm{mM}$ and in $\mathrm{Fe}^{2+}$ concentration-dependent manner [300, 150, and $\left.30 \mu \mathrm{M}\right]$.

When $\mathrm{Fe}^{2+}$ and $\mathrm{H}_{2} \mathrm{O}_{2}$ were applied together, $\mathrm{Fe}^{2+}$ enhanced $\mathrm{H}_{2} \mathrm{O}_{2}$ damaging effect to a higher degree than did $\mathrm{H}_{2} \mathrm{O}_{2}$ on $\mathrm{Fe}^{2+}$ effect.

Conclusions: The level of oxidized nucleosides in thyroid mtDNA is relatively high, when compared to nuclear DNA. Both substrates of Fenton reaction, i.e. ferrous ion and hydrogen peroxide, increase oxidative damage to mtDNA, with stronger damaging effect exerted by iron. High level of oxidative damage to mtDNA suggests its possible contribution to malignant transformation of thyroid oncocytic cells, which are known to be especially abundant in mitochondria, the latter characterized by molecular and enzymatic abnormalities.

Keywords: Mitochondrial DNA, Thyroid, Ferrous ion, Hydrogen peroxide, Oxidative damage

\footnotetext{
*Correspondence: MKarbownik@hotmail.com

'Department of Oncological Endocrinology, Medical University of Łódź, 7/9

Żeligowski St, 90-752, Łódź, Poland

${ }^{3}$ Polish Mother's Memorial Hospital - Research Institute, 281/289, Rzgowska

St, 93-338, Łódź, Poland

Full list of author information is available at the end of the article
} 


\section{Background}

Reactive oxygen species (ROS) are generated in animal cells as natural by-products of oxygen metabolism. They participate in numerous important life processes, like cell signaling or host defense against pathogens $[1,2]$. On the other hand, due to highly reactive nature, ROS are potentially very toxic and they can damage macromolecules, such as DNA, proteins and lipids. Normally, the cell is able to maintain an adequate balance between the formation and removal of ROS. However, when the levels of ROS increase, this balance may be disturbed, leading to oxidative stress, a condition involved in the pathogenesis of many diseases [1,3-5].

The most basic reaction of oxidative stress is Fenton reaction:

$$
\mathrm{Fe}^{2+}+\mathrm{H}_{2} \mathrm{O}_{2} \rightarrow \mathrm{Fe}^{3+}+{ }^{\cdot} \mathrm{OH}+\mathrm{OH}^{-}
$$

Hydroxyl radical $\left({ }^{\bullet} \mathrm{OH}\right)$ - being the most harmful free radical - is produced during the above reaction. Both substrates of Fenton reaction are normally present in thyroid cells and possess important physiological roles.

$\mathrm{H}_{2} \mathrm{O}_{2}$ is an indispensable factor in the process of thyroid hormone synthesis, acting as an electron acceptor at each step of this process, namely, at iodide oxidation, next, at its organification, as well as at iodotyrosine coupling reactions [6]. $\mathrm{H}_{2} \mathrm{O}_{2}$ is synthesized in the thyroid gland by certain enzymes of a dual oxidase/NADPH oxidase family (NOX/DUOX), with the most convincing experimental evidence found for DUOX2, acting mainly at the apical membrane or extracelluary - in the colloid [7] and for NOX4, acting intracellulary [8]. $\mathrm{H}_{2} \mathrm{O}_{2}$ availability is the rate-limiting step in thyroid hormone biosynthesis, although $\mathrm{H}_{2} \mathrm{O}_{2}$ is produced in large excess compared to the amount of iodide incorporated into proteins. This may be due to relatively high MichaelisMenten constant of thyroperoxidase (TPO) for $\mathrm{H}_{2} \mathrm{O}_{2}$, which means that relatively high concentrations of $\mathrm{H}_{2} \mathrm{O}_{2}$, as a substrate, are required to properly activate the enzyme $[9,10]$. It should be stressed that the stimulated thyroid cell generates as much $\mathrm{H}_{2} \mathrm{O}_{2}$ as an activated leukocyte [11]. Large quantities and membrane permeable nature of $\mathrm{H}_{2} \mathrm{O}_{2}$ can lead to its diffusion from the luminal side of the apical membrane back to the cell, potentially creating conditions for a huge oxidative stress.

Iron is an essential element for normal metabolic processes, being a cofactor for many biological reactions. On the other hand, free ionic iron, as a potent generator of ROS, can enhance oxidative stress. In the thyroid gland, iron is bound to TPO and it is required for its biological activity. Activated TPO (hemoprotein) constitutes only approximately $2 \%$ of total TPO; it is located in the apical membrane and it exposes its heme-linked catalytic site facing the thyroid follicular lumen $[12,13]$. This kind of iron compartmentalization constitutes, in a certain sense, defense mechanisms against oxidative damage in the thyroid, caused by heme iron.

Bivalent iron (ferrous ion; $\mathrm{Fe}^{2+}$ ) and/or $\mathrm{H}_{2} \mathrm{O}_{2}$ which when used together - initiate Fenton reaction, are frequently used to experimentally induce oxidative damage to macromolecules [6,14-22]. Thus, the present study is the next approach to evaluate oxidative damage to macromolecules caused by Fenton reaction substrates but the first one, in which thyroid mtDNA has been used.

Mitochondria remain the main source of ROS, even in thyroid tissue. Furthermore, they are the only cellular organelles in cells that contain their own DNA. This mitochondrial DNA (mtDNA) lies in close proximity to the free radical-producing electron transport chain and it is not protected by histones and polyamines, thus it is highly prone to oxidative damage. Additionally, lack of buffering structures, such as introns, also renders mtDNA more prone to mutations [23]. Consistently, it has been reported that mtDNA is characterized by a higher level of oxidative DNA damage than nuclear DNA [24]. In human mtDNA, over 150 pathogenic mutations have been identified; there is evidence that these mutations lead to a wide variety of degenerative diseases, preferentially in tissues with high energy demands, such as the central nervous system, heart, skeletal muscles and endocrine system [25]. Accumulation of somatic mutations in mtDNA causes deficiencies in oxidative phosphorylation and the electron transport chain, which, in turn, cause both further increased production of ROS and their leakage into the cytoplasm.

The aim of the study was to evaluate the background level of oxidative damage to thyroid mtDNA and the damaging effects of Fenton reaction substrates. Since 8-oxo-7,8-dihydro-2'-deoxyguanosine (8-oxodG) is a major product of oxidatively damaged DNA, this oxidized nucleoside has been used to evaluate oxidative damage to mtDNA. It should be stressed that the level of 8-oxodG, resulting from oxidative mtDNA damage, has never been examined in the thyroid gland under any conditions.

\section{Methods}

\section{Ethical approval}

The procedures, used in the study, were approved by the Ethics Committee of the Medical University of Lodz, Poland.

\section{Chemicals}

Ferrous sulfate $\left(\mathrm{FeSO}_{4}\right)$, hydrogen peroxide $\left(\mathrm{H}_{2} \mathrm{O}_{2}\right)$, alkaline phosphatase and nuclease $\mathrm{P}_{1}$ were purchased from Sigma (St. Louis, MO). MilliQ-purified $\mathrm{H}_{2} \mathrm{O}$ was used for preparing all solutions. All the used chemicals were of analytical grade and came from commercial sources. 


\section{Animals}

Porcine thyroids were collected from sixty three (63) animals at a slaughter-house, frozen on solid $\mathrm{CO}_{2}$, and stored at $-80^{\circ} \mathrm{C}$ until assay. Three independent experiments were performed. Therefore, three tissue pools were prepared, with twenty one (21) thyroid glands used for each experiment.

\section{Mitochondrial DNA isolation}

Mitochondrial DNA was isolated using an alkaline lysis method [26]. Thyroid tissue was homogenized in chilled homogenization buffer $(0.25 \mathrm{M}$ sucrose, $10 \mathrm{mM}$ EDTA, $30 \mathrm{mM}$ Tris $-\mathrm{HCl}, \mathrm{pH} 7.5)$ and centrifuged at $1000 \times \mathrm{g}$ for $3 \mathrm{~min}$ at $4^{\circ} \mathrm{C}$ in order to pellet the nuclei and cellular debris. The supernatant was centrifuged again at 12,000 $\times$ g for $10 \mathrm{~min}$ at $4^{\circ} \mathrm{C}$, to obtain pellet of mitochondria. This pellet was resuspended in $10 \mathrm{mM}$ Tris-EDTA buffer (containing $0.15 \mathrm{M} \mathrm{NaCl}$ and $10 \mathrm{mM}$ EDTA, pH 8.0) and then two volumes of freshly prepared $0.18 \mathrm{M} \mathrm{NaOH}$, containing $1 \%$ SDS, were added. After 5 min incubation on ice, solution of ice-cold potassium acetate (3 M potassium and $5 \mathrm{M}$ acetate) was added. After another $5 \mathrm{~min}$ incubation on ice, mixture was centrifuged at $12,000 \times \mathrm{g}$ for $5 \mathrm{~min}$ at $4^{\circ} \mathrm{C}$. The obtained supernatant was mixed with an equal volume of phenol/chloroform/isoamyl-alcohol (25:24:1) mixture. After centrifugation at 12,000 $\times \mathrm{g}$ for $5 \mathrm{~min}$ at room temperature, mtDNA was precipitated by the addition of five volumes of ethanol $\left(-20^{\circ} \mathrm{C}\right)$.

\section{Mitochondrial DNA incubation}

Mitochondrial DNA was incubated in $10 \mathrm{mM}$ potassium phosphate buffer ( $\mathrm{pH} 7.4)$ at a final volume of $0.5 \mathrm{ml}$ in the presence of either $\mathrm{H}_{2} \mathrm{O}_{2}[100,10,1.0,0.5,0.1,0.001$, 0.00001 or $0.0 \mathrm{mM}]$ or $\mathrm{FeSO}_{4}[300,150,30,15,3.0,1.5$, or $0.0 \mu \mathrm{M}$ ] or in the presence of those two agents used together, namely $\mathrm{FeSO}_{4}[30 \mu \mathrm{M}]+\mathrm{H}_{2} \mathrm{O}_{2}$ [100, 10, 1.0, $0.5,0.1,0.001,0.00001$ or $0.0 \mathrm{mM}]$ or $\mathrm{H}_{2} \mathrm{O}_{2}[0.5 \mathrm{mM}]+$ $\mathrm{FeSO}_{4}[300,150,30,15,3.0,1.5$, or $0.0 \mu \mathrm{M}]$. The reaction was carried out at $37^{\circ} \mathrm{C}$ for $1 \mathrm{hr}$ in a water bath. Three independent experiments were performed, and in each experiment mtDNA was isolated from twenty one (21) different thyroid glands.

\section{Evaluation of the 8-oxo-7,8-dihydro-2'deoxyguanosine/2'- deoxyguanosine (8-oxodG/dG) ratio}

After incubation, $50 \mu \mathrm{l}$ of sodium acetate ( $3 \mathrm{M}, \mathrm{pH} 5.0$ ) and two volumes of ethanol $\left(20^{\circ} \mathrm{C}\right)$ were added to each sample to terminate the reaction. DNA was precipitated by centrifugation $(13,000 \times \mathrm{g}, 5 \mathrm{~min})$; DNA was washed once with $70 \%$ ethanol. Thereafter, the DNA sample was dried and dissolved in $20 \mathrm{mM}$ sodium acetate $(\mathrm{pH} \mathrm{5.0)}$; the samples were denatured by heating at $95^{\circ} \mathrm{C}$ for $10 \mathrm{~min}$ and, then, cooled on ice for $5 \mathrm{~min}$. The DNA samples were digested to nucleotides by incubation with 8 units of nuclease $\mathrm{P}_{1}$ at $37^{\circ} \mathrm{C}$ for $30 \mathrm{~min}$. Next, $\mathrm{pH}$ was adjusted by adding $20 \mu \mathrm{l}$ of $1 \mathrm{M}$ Tris- $\mathrm{HCl}$ and the samples were treated with 4 units of alkaline phosphatase at $37^{\circ} \mathrm{C}$ for $1 \mathrm{hr}$. The resulting deoxynucleoside mixture was filtered through a Millipore filter $(0.22 \mathrm{~mm})$ and analyzed by HPLC with electrochemical (EC) detection. The HPLC system consisted of a Smartline Pump 1000, Smartline Autosampler 3800, $250 \mathrm{~mm} \times 4 \mathrm{~mm}$ Eurosphere100 C18 column and electrochemical detector EC3000 with measurement cell model Sputnik. An eluent (10\% aqueous methanol containing $12.5 \mathrm{mM}$ citric acid, $25 \mathrm{mM}$ sodium acetate, $30 \mathrm{mM}$ sodium hydroxide and $10 \mathrm{mM}$ acetic acid) was used at a flow rate of $1 \mathrm{ml} / \mathrm{min}$. The quantities of 8-oxo-7,8-dihydro-2'-deoxyguanosine (8-oxodG) and of 2'-deoxyguanosine $(\mathrm{dG})$ were measured using two oxidative potentials $(600 \mathrm{mV}, 900 \mathrm{mV}$, respectively). The results are expressed as the ratio of 8-oxodG to dG $\times 10^{5}$.

\section{Statistical analyses}

Results represent means $\pm \mathrm{SE}$. Data were statistically analyzed, using a one-way analysis at variance (ANOVA), followed by the Student-Neuman-Keuls' test. The level of $\mathrm{p}<0.05$ was accepted as statistically significant.

\section{Results}

The incubation of mtDNA in the presence of either $\mathrm{H}_{2} \mathrm{O}_{2}$ (Figure 1) or ferrous ions (Figure 2) increased the level of oxidative damage, namely the level of 8-oxodG increased significantly when $\mathrm{H}_{2} \mathrm{O}_{2}$ was used in the highest concentration of $100 \mathrm{mM}$ (Figure 1), and $\mathrm{Fe}^{2+}$ increased 8-oxodG level in concentration-dependent manner (for concentrations of 300, 150, $30 \mu \mathrm{M}$ ) (Figure 2).

When $\mathrm{Fe}^{2+}[30 \mu \mathrm{M}]$ was used together with different concentrations of $\mathrm{H}_{2} \mathrm{O}_{2}, 8$-oxodG level in mtDNA increased significantly in $\mathrm{H}_{2} \mathrm{O}_{2}$ concentration-dependent manner (Figure 3). When comparing Figures 1 and 3, the damaging effect of both substrates used together has been much more stronger comparing to damaging effect of $\mathrm{H}_{2} \mathrm{O}_{2}$ alone. First, the range of $\mathrm{H}_{2} \mathrm{O}_{2}$ concentrations [100 $\mathrm{mM}, 10 \mathrm{mM}$ and $1 \mathrm{mM}$ ], which have increased 8-oxodG level, is wider in the presence of $\mathrm{Fe}^{2+}$. Second, 8 -oxodG level is approximately $4 \times$ higher in the presence of $\mathrm{H}_{2} \mathrm{O}_{2}[100 \mathrm{mM}]$ plus $\mathrm{Fe}^{2+}$ when compared to the effect of $\mathrm{H}_{2} \mathrm{O}_{2} \quad[100 \mathrm{mM}]$ alone. This suggests that the addition of $\mathrm{Fe}^{2+}$ strongly enhanced the effect of $\mathrm{H}_{2} \mathrm{O}_{2}$.

In turn, when $\mathrm{H}_{2} \mathrm{O}_{2}$ [0.5 mM] was used together with different concentrations of $\mathrm{Fe}^{2+}, 8$-oxodG level in mtDNA increased significantly in $\mathrm{Fe}^{2+}$ concentrationdependent manner (Figure 4). These effect was observed for exactly the same concentrations [300, 150 and $30 \mu \mathrm{M}$ ], as when ferrous ion was used separately (compare with Figure 2). However, 8-oxodG level was above 


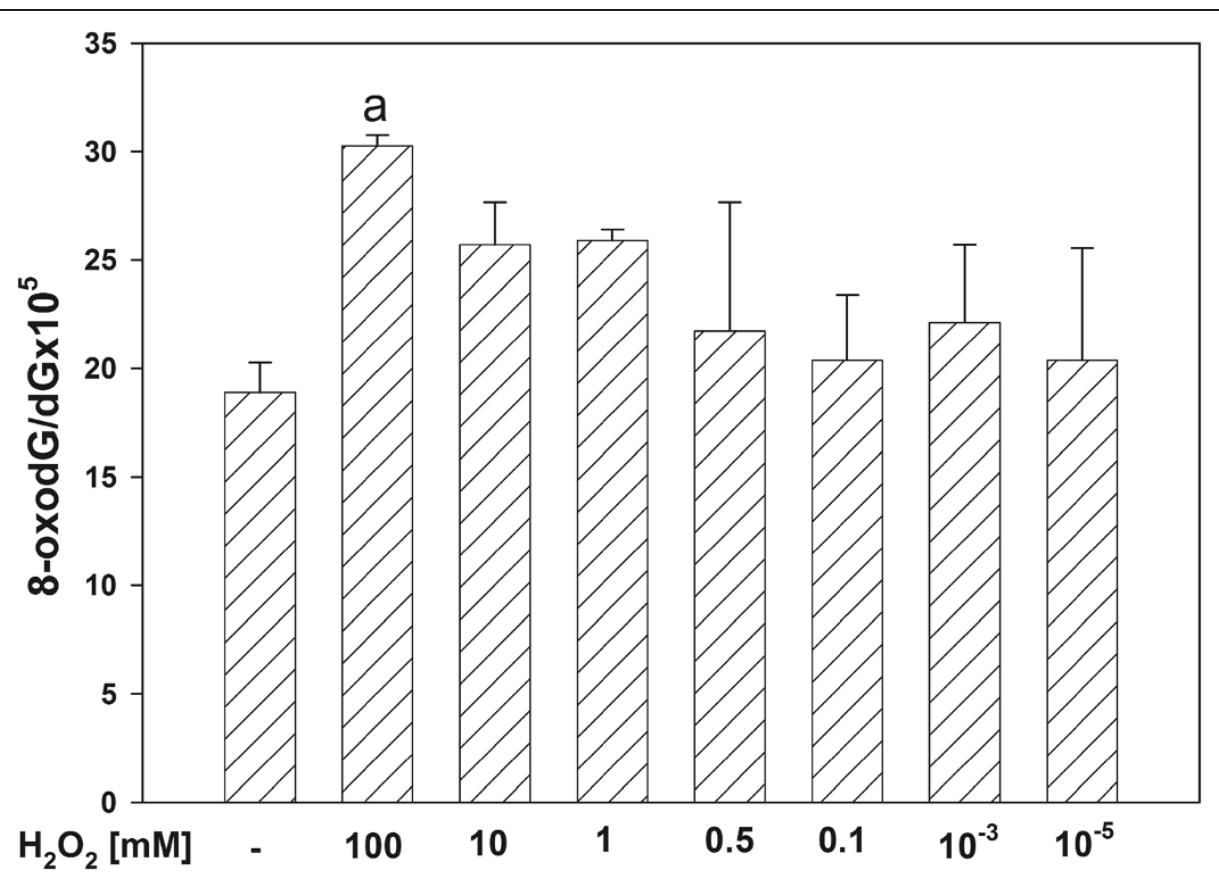

Figure 1 Oxidative damage to mitochondrial DNA in porcine thyroid. mtDNA was incubated in the presence of $\mathrm{H}_{2} \mathrm{O}_{2}$ alone $[100,10,1.0,0.5$, $0.1,0.001,0.00001 \mathrm{mM}$. Data are expressed as the ratio 8-oxodG/dG $\times 10^{5}$. Data are from three independent experiments. Values are expressed as mean $\pm \mathrm{SE}$ (error bars). ${ }^{\mathrm{a}} \mathrm{p}=0.05 \mathrm{vs}$. control (in the absence of $\mathrm{H}_{2} \mathrm{O}_{2}$ ).

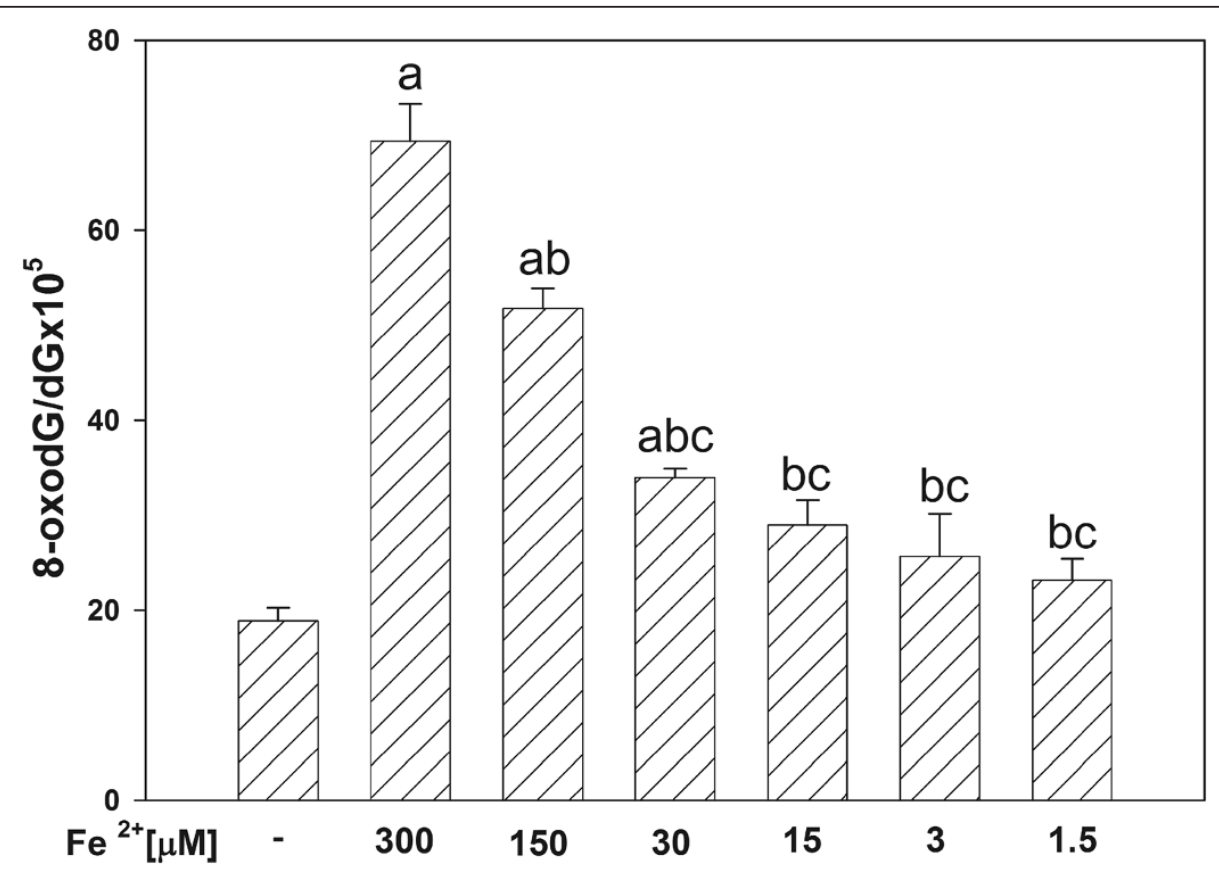

Figure 2 Oxidative damage to mitochondrial DNA in porcine thyroid. mtDNA was incubated in the presence of $\mathrm{FeSO}_{4}\left(\mathrm{Fe}^{2+}\right)$ alone $[300$, $150,30,15,3.0,1.5 \mu \mathrm{M}]$. Data are expressed as the ratio 8-oxodG/dGX10 ${ }^{5}$. Data are from three independent experiments. Values are expressed as mean \pm SE (error bars). ${ }^{a} p=0.05$ vs. control (in the absence of Fe ${ }^{2+}$, , ${ }^{b} p=0.05$ vs. $300 \mu \mathrm{M},{ }^{c} p=0.05$ vs. $150 \mu \mathrm{M}$. 


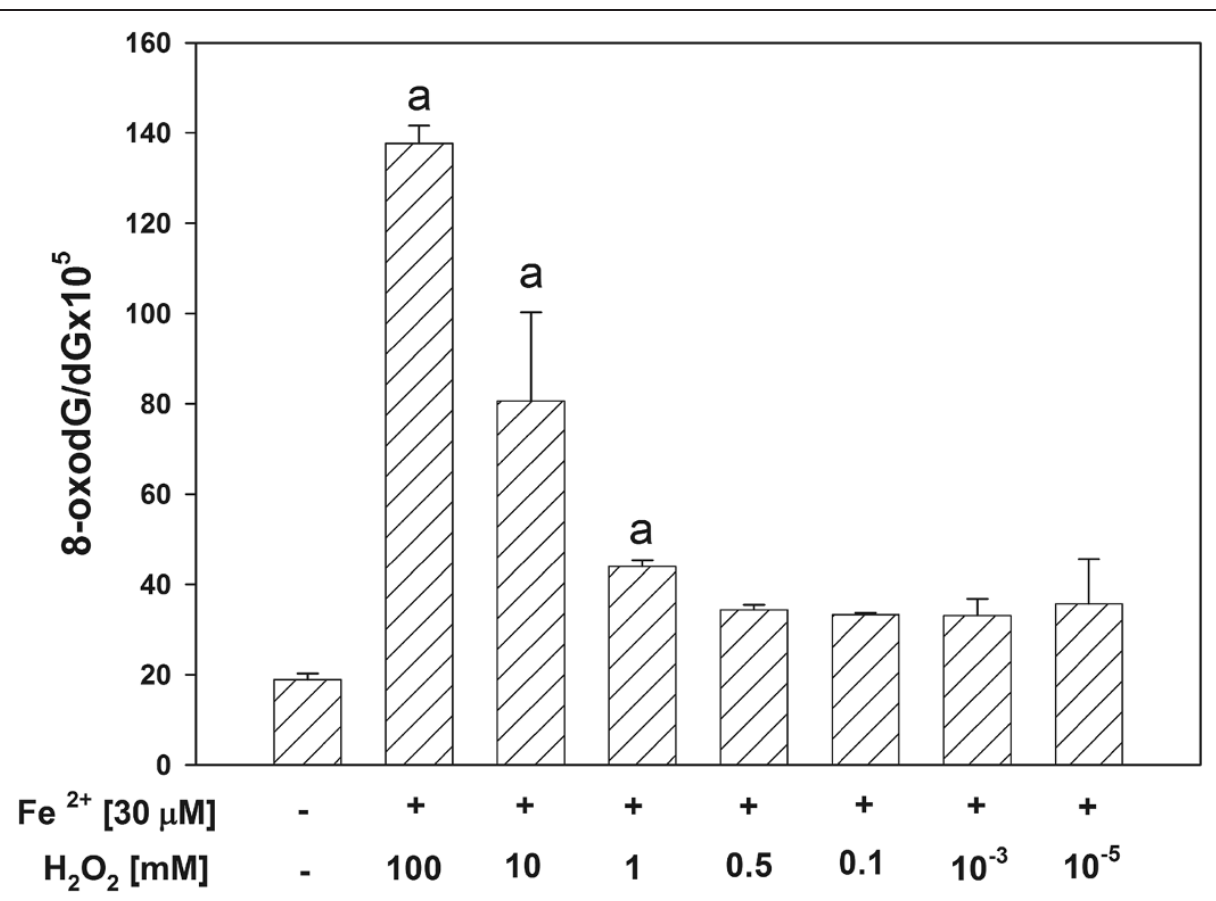

Figure 3 Oxidative damage to mitochondrial DNA in porcine thyroid. mtDNA was incubated in the presence of both substrates used together, namely in the presence of $30 \mu \mathrm{M} \mathrm{FeSO}_{4}$ plus $\mathrm{H}_{2} \mathrm{O}_{2}[100,10,1.0,0.5,0.1,0.001,0.00001 \mathrm{mM}]$. Data are expressed as the ratio 8-oxodG/ $\mathrm{dG} \times 10^{5}$. Data are from three independent experiments. Values are expressed as mean $\pm \mathrm{SE}$ (error bars). ${ }^{\mathrm{a}} \mathrm{p}=0.05 \mathrm{vs}$. control (in the absence of both $\mathrm{Fe}^{2+}$ and $\mathrm{H}_{2} \mathrm{O}_{2}$ ).

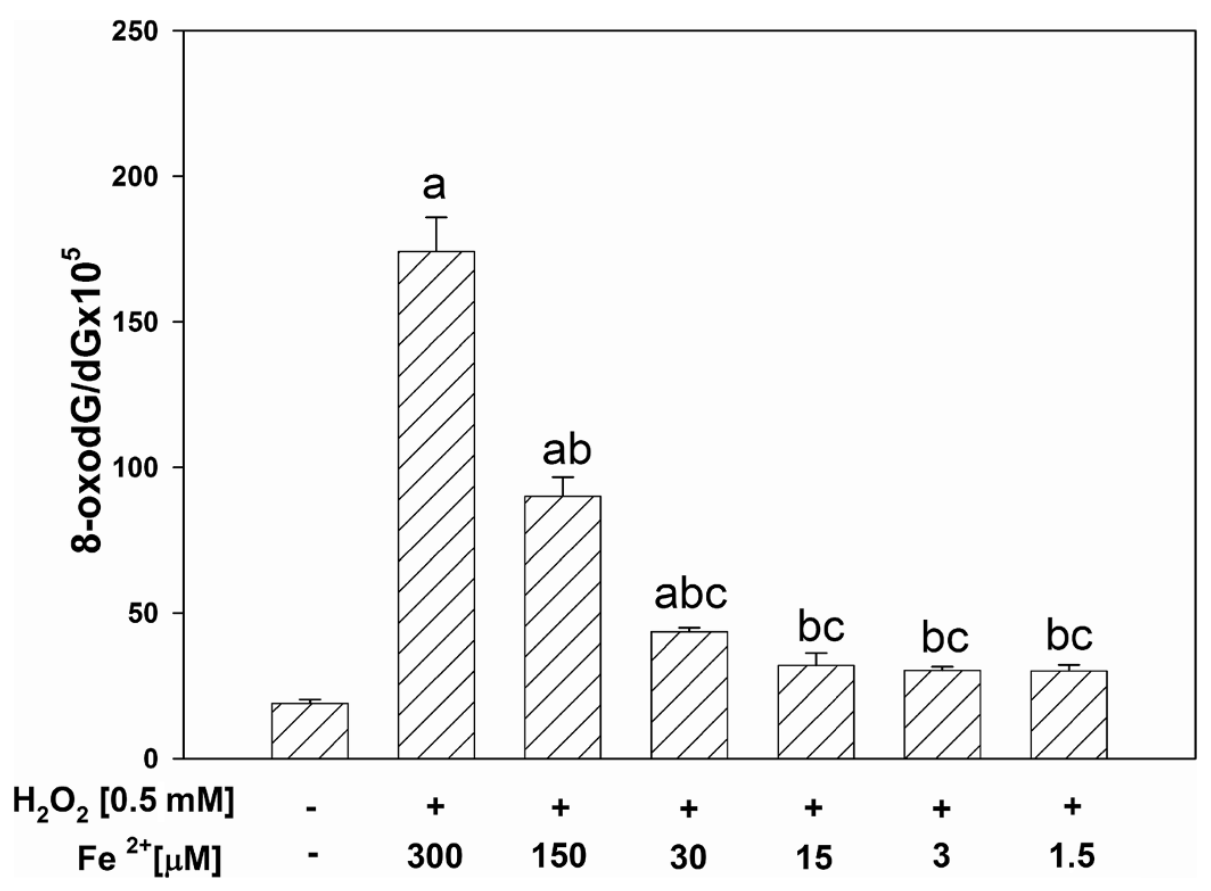

Figure 4 Oxidative damage to mitochondrial DNA in porcine thyroid. mtDNA was incubated in the presence of both substrates used

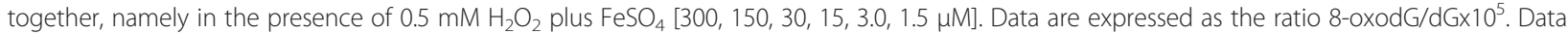
are from three independent experiments. Values are expressed as mean $\pm \mathrm{SE}$ (error bars). ${ }^{\mathrm{a}} \mathrm{p}=0.05 \mathrm{Vs}$. control (in the absence of both Fe ${ }^{2+}$ and $\left.\mathrm{H}_{2} \mathrm{O}_{2}\right),{ }^{b} p=0.05$ vs. $300 \mu \mathrm{M},{ }^{c} p=0.05$ vs. $150 \mu \mathrm{M}$. 
$2 \times$ higher in the presence of $\mathrm{Fe}^{2+}[300 \mu \mathrm{M}]$ plus $\mathrm{H}_{2} \mathrm{O}_{2}$ $[0.5 \mathrm{mM}]$ (Figure 4) than in the presence of $\mathrm{Fe}^{2+}$ $[300 \mu \mathrm{M}]$ alone (Figure 2). The difference between damaging effects of $\mathrm{Fe}^{2+}+\mathrm{H}_{2} \mathrm{O}_{2}$ and $\mathrm{Fe}^{2+}$ alone is not so obvious for two other lower $\mathrm{Fe}^{2+}$ concentrations, namely for $150 \mu \mathrm{M}$ and $30 \mu \mathrm{M}$. The results suggest that the addition of $\mathrm{H}_{2} \mathrm{O}_{2}$ enhanced the effect of $\mathrm{Fe}^{2+}$.

It should be stressed that $\mathrm{Fe}^{2+}$ intensified the damaging effect of $\mathrm{H}_{2} \mathrm{O}_{2}$ stronger than $\mathrm{H}_{2} \mathrm{O}_{2}$ intensified the damaging effect of $\mathrm{Fe}^{2+}$.

\section{Discussion}

In mitochondrial and nuclear DNA, 8-oxodG is the most abundant oxidatively damaged product following the exposure to free radicals, and - therefore - it is widely used as a biomarker of oxidative stress and carcinogenesis. According to our knowledge, this study is the first one, in which the level of oxidized nucleosides in mtDNA in the thyroid gland has been measured. The fact that the attempt to measure oxidative damage to mtDNA in the thyroid has not been undertaken before may be due to technical difficulties occurring during mtDNA isolation from the thyroid. In the process of mtDNA isolation significant amount of the mtDNA is lost, especially at the step of isolation of the whole mitochondria; therefore, much more tissue is required and the procedure is more time-consuming, comparing to nuclear DNA isolation.

When designing this study, we expected that physiological damage to mtDNA would be much higher than that one to nuclear DNA. Expectedly, the background oxidative damage to mtDNA in the present study (8-oxodG/dG $\times 10^{5}=$ from 15.96 to 21.32 ) was approximately ten (10) times higher than to nuclear DNA, the latter being observed in our earlier study (8-oxodG $/ \mathrm{dG} \times 10^{5}=$ from 2.24 to 2.80 ) [27]. These results are in agreement with data already presented in numerous published studies concerning other tissues. Values for the ratio of mitochondrial to nuclear levels of 8-oxodG range from 2 (in human fibroblasts) [28] to 16 (in rat liver) [24]. That significantly higher background oxidative damage in mtDNA appears to represent evidence for more extensive oxidation of mtDNA comparing to nuclear DNA under physiological conditions. Main reasons for higher sensitivity to oxidative stress of mtDNA, comparing to nuclear DNA, comprise mentioned above such characteristics as proximity of mtDNA to the mitochondrial electron transport chain, being a site of superoxide anion $\left(\mathrm{O}_{2}^{-*}\right)$ and $\mathrm{H}_{2} \mathrm{O}_{2}$ generation, as well as the lack of protective histones. It should be also stressed that mtDNA does not possess introns, therefore, the whole mtDNA when exposed to free radicals - can be damaged.
It should be mentioned that in the last years certain doubts arose concerning the reliability of the measurement of mtDNA oxidation. The question to what extent mitochondrial 8-oxodG levels, measured in experimental conditions, correspond to those typical for physiological conditions (in the living organism) has not been yet adequately answered. Some authors argue, that additional oxidative damage might be induced during the procedure of mitochondria isolation. According to this hypothesis, during the process of mitochondria isolation, organelles may continue to generate oxygen radicals which can contribute to increase ex vivo oxidation. Moreover, mitochondria contain large quantities of heme protein with redox-active iron atom, which also may cause extensive oxidation during the isolation [29]. However, it should be underlined that the above hypothesis has not been univocally proved. In turn, even if any additional oxidation occurs during mitochondria isolation or, later on, before 8-oxodG measurement, it is still unknown to what extent such an oxidation contributes to the final result. High ratio of mitochondrial/nuclear 8-oxodG, mentioned above and described for different tissues [29], as well as the value of that ratio equal to 10 , as observed by us in the thyroid in the present study, support the statement that oxidative damage to mtDNA is much stronger than that directed against nuclear DNA.

Another aspect which should be discussed in the present study is the sensitivity of thyroid mtDNA to Fenton reaction substrates. In our present study, addition of a single Fenton reaction substrate was sufficient to increase 8-oxodG level in mtDNA. The damaging effects of Fenton reaction substrates, when used separately, suggest that exogenous ferrous ion and exogenous $\mathrm{H}_{2} \mathrm{O}_{2}$ reacted with the other substrate present already (physiologically) in mtDNA. Thus, the exposure to only one of these factors can cause oxidative damage to mtDNA. When both Fenton reaction substrates were applied together, elevations in 8-oxodG levels were, expectedly, higher than those when they were used separately. It should be stressed that ferrous ion revealed stronger damaging effect than $\mathrm{H}_{2} \mathrm{O}_{2}$, both when the substrates were used separately or were applied together. The results on oxidative mtDNA damage suggest that in the thyroid gland iron is a more potent prooxidative factor, when compared to $\mathrm{H}_{2} \mathrm{O}_{2}$. These results are in agreement with our observation for nuclear DNA and also for membrane lipids in our previous study [27]. In turn, as regards the response of nuclear DNA [27] and mtDNA (the present study) to Fenton reaction substrates, mtDNA seems to be less vulnerable. Such results have been expected, as macromolecules with physiologically high oxidative damage are usually less sensitive to additional oxidative abuse. However, the differences in the oxidative response of mtDNA and nuclear DNA 
are not obvious enough to draw final conclusions as to which of these two kinds of DNA is more sensitive to Fenton reaction substrates.

What is a clinical significance of the present findings is not clear enough. Our results show that excessive amounts of $\mathrm{Fe}^{2+}$ or $\mathrm{H}_{2} \mathrm{O}_{2}$ contribute to the increased oxidative damage to mtDNA which, in turn, can lead to mutations, impairment of electron transport chain and loss of mitochondrial functions. Decline of the mitochondria respiratory functions is generally accepted as an important contributor to aging and wide range of degenerative diseases. Dysfunction of mitochondria are also suggested to be a predominant feature in oncocytic tumor transformation. Oncocytic neoplasms are the tumours composed of cells filled - almost exclusively with mitochondria characterized by molecular and enzymatic abnormalities. They mainly occur in endocrine and exocrine tissues but also have been observed in other organs [23,30]. In the thyroid gland, oncocytic cells (also known as Hürtle cells or oxyphilic cells) are frequently observed in benign and malignant tumors, as well as in chronic inflammatory conditions or in hyperplastic lesions. Hürtle cells are characterized by blocked apoptosis, probably as a consequence of mitochondrial abnormalities. The main reason responsible for oncocytic transformation can be compensatory mechanism, in which the activation of mitochondrial biogenesis pathways constitutes the response to metabolic stress, caused by loss of mitochondrial function. This leads to increase of mitochondrial mass and further intensifies oxidative stress.

Oxidative stress is hypothesized to play a crucial role in thyroid cancer, especially in papillary thyroid carcinoma, initiation [31]. However, the present results allow to propose that oxidative processes substantially contribute to formation of tumors, with oxyphilic type of follicular thyroid carcinoma being of special significance. The frequency of this type of cancer is much lower than one should expect, taking into account huge oxidative damage to mtDNA under normal conditions. It is assumed that - due to enormous oxidative stress in mitochondria defense mechanisms are perfectly developed in these organelles under physiological conditions, preventing serious consequences, such as cancer. However, with additional insult, the protective mechanisms may be disrupted and the formation of ROS may be even higher, leading to the initiation of thyroid cancer, composed of cells rich in abnormal mitochondria. Further studies are required to confirm such a hypothesis.

\section{Conclusions}

The level of oxidized nucleosides in thyroid mtDNA is relatively high, when compared to nuclear DNA. Both substrates of Fenton reaction, i.e. ferrous ion and hydrogen peroxide, increase oxidative damage to mtDNA, with stronger damaging effect exerted by iron. High level of oxidative damage to mtDNA suggests its possible contribution to malignant transformation of thyroid oncocytic cells, which are known to be especially abundant in mitochondria, the latter characterized by molecular and enzymatic abnormalities.

\section{Competing interests}

Authors declare that they have no competing interests.

\section{Authors' contributions}

MK- $L$ designed the study, supervised its conducting and prepared the final version of the manuscript. JS carried out the experiments, performed the statistical evaluation and prepared the draft of the manuscript. AL revised the final version of the manuscript. All authors read and approved the final manuscript.

\section{Acknowledgement}

The research was supported by the statutory funds No. 503/1-107-03/503-01 from the Medical University of Łódź.

\section{Author details}

${ }^{1}$ Department of Oncological Endocrinology, Medical University of Łódź, 7/9 Żeligowski St, 90-752, Łódź, Poland. ²Department of Endocrinology and Metabolic Diseases, Medical University of Łódź, 281/289 Rzgowska St, 93-338, Łódź, Poland. ${ }^{3}$ Polish Mother's Memorial Hospital - Research Institute, 281/ 289, Rzgowska St, 93-338, Łódź, Poland.

Received: 26 September 2012 Accepted: 7 December 2012

Published: 26 December 2012

\section{References}

1. Halliwell B: Free radicals and antioxidants: updating a personal view. Nutr Rev 2012, 70:257-265.

2. Ray PD, Huang BW, Tsuji Y: Reactive oxygen species (ROS) homeostasis and redox regulation in cellular signaling. Cell Signal 2012, 24:981-990.

3. Lau AT, Wang Y, Chiu JF: Reactive oxygen species: current knowledge and applications in cancer research and therapeutic. J Cell Biochem 2008, 104:657-667.

4. Valko M, Leibfritz D, Moncol J, Cronin MT, Mazur M, Telser J: Free radicals and antioxidants in normal physiological functions and human disease. Int J Biochem Cell Biol 2007, 39:44-84.

5. Ziech D, Franco R, Pappa A, Panayiotidis Ml: Reactive oxygen species (ROS)-induced genetic and epigenetic alterations in human carcinogenesis. Mutat Res 2011, 711:167-173.

6. Karbownik M, Lewiński A: Melatonin reduces Fenton reaction-induced lipid peroxidation in porcine thyroid tissue. J Cell Biochem 2003, 90:806-811.

7. Dupuy C, Ohayon R, Valent A, Noel-Hudson MS, Deme D, Virion A: Purification of a novel flavoprotein involved in the thyroid NADPH oxidase: cloning of the porcine and human CDNAs. J Biol Chem 1999, 274:37265-37269.

8. Weyemi U, Caillou B, Talbot M, Ameziane-El-Hassani R, Lacroix L, LagentChevallier O, Al Ghuzlan A, Roos D, Bidart JM, Virion A, Schlumberger M, Dupuy $C$ : Intracellular expression of reactive oxygen species-generating NADPH oxidase NOX4 in normal and cancer thyroid tissues. Endocr Relat Cancer 2010, 17:27-37.

9. Corvilain B, Laurent E, Lecomte M, Van Sande J, Dumont JE: Role of the cyclic adenosine 3,5-monophosphate and the phosphatidylinositol-Ca2+ cascades in mediating the effects of thyrotropin and iodide on hormone synthesis and secretion in human thyroid slices. J Clin Endocrinol Metab 1994, 79:152-159.

10. Rousset B, Poncet $C$, Dumont JE, Mornex R: Intracellular and extracellular sites of iodination in dispersed hog thyroid cells. Biochem J 1980, 192:801-812.

11. Song $Y$, Driessens $N$, Costa $M$, De Deken X, Detours V, Corvilain B, Maenhaut C, Miot F, Van Sande J, Many MC, Dumont JE: Roles of hydrogen peroxide in thyroid physiology and disease. J Clin Endocrinol Metab 2007, 92:3764-3773. 
12. Ruf J, Carayon P: Structural and functional aspects of thyroid peroxidase. Arch Biochem Biophys 2006, 445:269-277.

13. Fayadat L, Niccoli-Sire P, Lanet J, Franc JL: Human thyroperoxidase is largely retained and rapidly degraded in the endoplasmic reticulum. Its $\mathrm{N}$-glycans are required for folding and intracellular trafficking. Endocrinology 1998, 139:4277-4285.

14. Cabrera J, Burkhardt S, Tan DX, Manchester LC, Karbownik M, Reiter RJ: Autoxidation and toxicant-induced oxidation of lipid and DNA in monkey liver: reduction of molecular damage by melatonin. Pharmacol Toxicol 2001, 89:225-230.

15. Gitto E, Tan DX, Reiter RJ, Karbownik M, Manchester LC, Cuzzocrea S, Fulia F, Barberi I: Individual and synergistic antioxidative actions of melatonin: studies with vitamin $\mathrm{E}$, vitamin $\mathrm{C}$, glutathione and desferrioxamine (desferoxamine) in rat liver homogenates. J Pharm Pharmacol 2001, 53:1393-1401.

16. Karbownik M, Reiter RJ, Garcia JJ, Tan D: Melatonin reduces phenylhydrazine-induced oxidative damage to cellular membranes: evidence for the involvement of iron. Int J Biochem Cell Biol 2000, 32:1045-1054.

17. Karbownik M, Gitto E, Lewiński A, Reiter RJ: Relative efficacies of indole antioxidants in reducing autoxidation and iron-induced lipid peroxidation in hamster testes. J Cell Biochem 2001, 81:693-699.

18. Karbownik M, Lewiński A, Reiter RJ: Anticarcinogenic actions of melatonin which involve antioxidative processes: comparison with other antioxidants. Int I Biochem Cell Biol 2001, 33:735-753.

19. Karbownik-Lewińska M, Steppniak J, Krawczyk J, Zasada K, Szosland J, Gesing A, Lewiński A: External hydrogen peroxide is not indispensable for experimental induction of lipid peroxidation via Fenton reaction in porcine ovary homogenates. Neuro Endocrinol Lett 2010, 31:343-347.

20. Mehta R, Dedina L, O'Brien PJ: Rescuing hepatocytes from iron-catalyzed oxidative stress using vitamins B1 and B6. Toxicol In Vitro 2011, 25:1114-1122

21. Natoli M, Felsani A, Ferruzza S, Sambuy Y, Canali R, Scarino ML: Mechanisms of defence from Fe(II) toxicity in human intestinal Caco-2 cells. Toxicol In Vitro 2009, 23:1510-1515.

22. Qi W, Reiter RJ, Tan DX, Garcia JJ, Manchester LC, Karbownik M, Calvo JR: Chromium(III)-induced 8-hydroxydeoxyguanosine in DNA and its reduction by antioxidants: comparative effects of melatonin, ascorbate, and vitamin E. Environ Health Perspect 2000, 108:399-402.

23. Gasparre G, Romeo G, Rugolo M, Porcelli AM: Learning from oncocytic tumors: Why choose inefficient mitochondria? Biochim Biophys Acta 2011, 1807:633-642

24. Richter C, Park JW, Ames BN: Normal oxidative damage to mitochondrial and nuclear DNA is extensive. Proc Natl Acad Sci USA 1988, 85:6465-6467.

25. Wallace DC: Mitochondrial DNA mutations in disease and aging. Environ Mol Mutagen 2010, 51:440-450

26. Tamura K, Aotsuka T: Rapid isolation method of animal mitochondrial DNA by the alkaline lysis procedure. Biochem Genet 1988, 26:815-819.

27. Stępniak J, Lewiński A, Karbownik-Lewińska M: Membrane lipids and nuclear DNA are differently susceptive to Fenton reaction substrates in porcine thyroid. Toxicol In Vitro 2013, 27:71-78.

28. Yakes FM, Van Houten B: Mitochondrial DNA damage is more extensive and persists longer than nuclear DNA damage in human cells following oxidative stress. Proc Natl Acad Sci USA 1997, 94:514-519.

29. Beckman KB, Ames BN: Endogenous oxidative damage of mtDNA. Mutat Res 1999, 424:51-58.

30. Máximo V, Lima J, Prazeres H, Soares P, Sobrinho-Simões M: The biology and the genetics of Hurthle cell tumors of the thyroid. Endocr Relat Cancer 2012, 19:R131-R147.

31. Detours $V$, Delys $L$, Libert $F$, Weiss Solís $D$, Bogdanova T, Dumont JE, Franc B, Thomas G, Maenhaut C: Genome-wide gene expression profiling suggests distinct radiation susceptibilities in sporadic and postChernobyl papillary thyroid cancers. Br J Cancer 2007, 97:818-825.

doi:10.1186/1756-6614-5-24

Cite this article as: Karbownik-Lewińska et al:: High level of oxidized nucleosides in thyroid mitochondrial DNA; damaging effects of Fenton reaction substrates. Thyroid Research 2012 5:24.

\section{Submit your next manuscript to BioMed Central and take full advantage of:}

- Convenient online submission

- Thorough peer review

- No space constraints or color figure charges

- Immediate publication on acceptance

- Inclusion in PubMed, CAS, Scopus and Google Scholar

- Research which is freely available for redistribution 